\title{
Fransızcanın rengi: Öğretmen adaylarının yabancı dil olarak Fransızcaya dair metaforik algıları ${ }^{1}$
}

\section{Melek ALPAR² \\ Erdoğan KARTAL3}

\begin{abstract}
APA: Alpar, M.; Kartal, E. (2019). Fransızcanın rengi: Öğretmen adaylarının yabancı dil olarak Fransızcaya dair metaforik algıları. RumeliDE Dil ve Edebiyat Araştırmaları Dergisi, (17), 405-416. DOI: $10.29000 /$ rumelide. 657875
\end{abstract}

\section{$\ddot{O} \mathbf{z}$}

Metaforlar, zihnimizdeki soyut ama aynı zamanda belirsiz kimi duygu ve düşüncelerin somutlaştırılarak ifade edilmesine yarayan söz sanatlarından biridir. Bu düşünceden hareketle, olgubilim (fenomonoloji) desenli olarak yapılandırılan bu nitel çalışmada, Gazi Üniversitesi Fransız Dili Eğitimi Anabilim Dalı öğrencilerinin yabancı dil olarak Fransızcaya dair algılarının renk metaforu aracılığıyla belirlenmesi ve bu metaforların (renklerin) seçiliş nedenlerinin ortaya konulması amaçlanmıştır. Kısacası, öğrencilerin eğitimleri süresince Fransızcaya dair algı ve düşüncelerinin neler olduğunu ve bu dile dair kafalarında nasıl bir resim oluşturdukları belirlenmeye çalışılmıştır. Araştırmanın çalışma grubu 2016-2017 bahar yarıylında bu anabilim dalında lisans 1. ve 4. sınıf düzeyinde öğrenim gören 62 gönüllü katılımcı öğrenciden oluşmaktadır. Öğrencilerin yabancı dil olarak Fransızca kavramına ilişkin metaforik algıları, Size göre Fransızca bir renk olsayd, bu renk ne olurdu ve niçin bu renk olurdu? gibi açık uçlu sorularla yarı yapılandırılmış görüşme formu aracıllğıyla elde edilmiştir. Metaforun (rengin) ne olabileceği ne renk soru sözcük öbeğiyle belirlenmeye çalışılırken Niçin soru ifadesi ile de metafor olarak tanımlanan rengin neden seçildiğinin arka planına ilişkin algıya/değerlendirmeye ulaşılmaya çalışılmıştır. Verilerin analizinde ise içerik analizi tekniğinden yararlanılmıştır.

Anahtar kelimeler: Yabancı dil olarak Fransızca, Fransızca öğrencileri, metafor, renk, algı, içerik analizi.

\section{The colour of French language: The metaphorical perceptions of prospective teachers on French as a foreign language}

\begin{abstract}
Metaphors are rhetorical arts that can help us to realize in our minds feelings and thoughts that are both abstract and ambiguous. In this spirit, in this qualitative study structured with a phenomenological design (phenomenology), our goal is to determine the perceptions of the students of the Department of Teaching French as a Foreign Language at the University of Gazi by means of a metaphor of colours and to reveal the reasons for the choice of these metaphors. In summary, during this research we tried to show the students' perception during their schooling of the French language,
\end{abstract}

\footnotetext{
1 Bu çalışma, 21-23 Eylül 2017 tarihleri arasında Nevşehir Hacı Bektaş Veli Üniversitesi tarafından Nevşehir'de düzenlenen I. Uluslararası İpekyolu Akademik Çahş̧malar Sempozyumu'nda aynı başlık altında sunulan bildirinin genişletilmiş halidir.

2 Doç. Dr., Gazi Üniversitesi, Gazi Eğitim Fakültesi, Fransız Dili Eğitimi ABD (Ankara, Türkiye), meleka@gazi.edu.tr, ORCID ID: oooo-0002-7416-293X [Makale kaylt tarihi: 17.10.2019-kabul tarihi: 20.12.2019; DOI: 10.29000/rumelide.657875]

3 Doç. Dr., Bursa Uludağ Üniversitesi, Eğitim Fakültesi, Fransız Dili Eğitimi ABD (Bursa, Türkiye), ekartal@uludag.edu.tr, ORCID ID: 0000-0002-9836-5221.
} 
The colour of French language: The metaphorical perceptions of prospective teachers on French as a foreign language / M. Alpar; E. Kartal (pp. 405-416)

\begin{abstract}
their various thoughts and to determine what image they have of this language. The study group of the research consists of 62 volunteers who are 1st and 4th year undergraduate students in this department during Spring Semester 2016-2017. The metaphorical perceptions of students on French as a foreign language were obtained in response to this half open-ended question: If French language was a colour, what colour do you think it would be and why? While the metaphor itself was tried to be determined with the what colour do you think it would be phrase, the statement why questioned the reasons behind this perception/judgement. The content analysis method has been used in the process of data analysis.
\end{abstract}

Keywords: French as a Foreign language, French language students, metaphor, colour, perception, content analysis.

\title{
1. Giriş
}

Kültürler tarih boyunca şekillenmiş yaşam tasarımlarıdır. Diğer taraftan bireysel ve toplumsal davranışları etkileyen kültür olgusu kendi toplumu yanında başka toplumları anlamak için de önemlidir (Alpar, 2019. s. 24). Bu husus dil konusunda yapılan çalışmalarda da karşımıza çıkar. Tarihsel gelişimi içerisinde Fransızca Türkiye'de öğretilen önemli yabancı dillerden birisi olmuştur. Fransızca geçmişte karşımıza Haçlı Seferleri (1096-1272) sırasında ortaya çıkar. Bir Avrupa ve Akdeniz ülkesi olan Fransa Hristiyan kimliği ile Haçlı Seferlerinde önemli bir rol oynamıştır. Fransızlar ve Türkler bu seferler sırasında ilk defa 1097 yılında İznik’te karşı karşıya gelmişlerdir (Yllancıoğlu, 2011, s. 47). Bu yıllarda Eskişehir yakınlarında Sultan 1. Kılıçarsan Fransız ve Alman ağır süvarileri ile giriştiği savaşta geri çekilmiş ancak bu Selçuklular için iyi bir ders olmuştur (Alpar, 2015, s. 170). II. Keyhüsrev döneminde ise 1000 kadar Frenk askeri Selçukluların emrinde görev yapmıştır. Aralarında yoğun ilişkiler bulunan her iki taraf şüphesiz o dönemde geçerli dillerin yanında kendi dilleri ile de iletişim kurmuşlardır. Böylelikle her iki ülke ilişkilerine dil unsuru da girmiş olur. Osmanlı döneminde ise özellikle İstanbul'da küçük bir Fransız topluluğu oluşmuş ve bunlar kiliseler yanında kurulan okullarda kendi dillerini öğrenmeye başlamışlardır. Osmanlılar özellikle İstanbul'da yaşayan dinsel toplulukların eğitimini yapan okulları resmen tanımıştır (Aksoy, 2015, s. 31).

Kanuni döneminde Fransızlarla artan ilişkiler dil konusunu da ileri bir safhaya taşımış ve Fransızca Osmanlı Devletinde giderek daha fazla yer bulmuştur. Özellikle gerileme döneminde Osmanlılar kendilerini yenilemek ve Batıdaki gelişmeleri takip etmek adına Batılı ülkelerin dillerini daha çok öğrenme gereğini hissetmişlerdir. Bu kapsamda ilk askeri denizcilik okulu olan Mühendishane-i Bahr-i Hümayun'da ders programlarına seçmeli dil olarak Fransızca konulmuştur (Sakaoğlu, 1991, s. 61). Daha sonra bu, diğer okullara yayılmıştır. Osmanlıların son dönemlerine gelindiğinde ise Fransızca konuşup yazmak modernleşmenin ve entelektüel görünmenin bir aracı gibi görülmeye başlanmıştır. 1908 yllından sonra ise Fransızcanın bütün okullarda zorunlu, İngilizce ve Almancanın ise seçmeli olarak okutulması esası getirilmiştir (Demirel, 1999, s. 7).

Cumhuriyet dönemine gelindiğinde ise Tevhid-i Tedrisat Kanunu (Öğretim Birliği Yasası, 3 Mart 1924)'nun kabulü ile birlikte Türkiye Cumhuriyeti’ndeki Fransız okullarında Türklere de eğitim verilmeye başlanmıştır. 1955 yılından sonra aralarında Fransızca eğitim veren okulların da bulunduğu yabancı dille eğitim veren birçok kolej açılmıştır. Günümüzde ise her ne kadar Fransızcanın etkisinin giderek azaldığı görülse de, Galatasaray okulları, Tevfik Fikret liseleri başta olmak üzere Fransız dilinde eğitim yapan okulların yanı sıra bazı okullarda seçmeli ders olarak Fransızca eğitim yapılmaktadır. Diğer taraftan son yıllarda İngilizce her ne kadar bir dünya dili (lingua franca) olarak kabul görse de yabancı 
dil olarak Fransızcanın tarihine bakıldığında bu dilin Türkler için her zaman ayrıcalıklı bir yerinin olduğu görülmektedir. Ayrıca İngilizceye nazaran öğrenilmesinin zor olması, daha çok elitler arasında ve diplomasi çevrelerinde konuşulan bir dil olması ve de edebi yönü sebebiyle aslında toplumumuzun bugün bile bu dili konuşanlara karşı büyük bir saygı ve hayranlık duyduğu söylenebilir.

\section{2. Çalışmanın önemi}

Bu yönleriyle düşünüldüğünde özellikle de ülkemizdeki eğitim fakültelerinin Fransızca öğretmenliği programlarında öğrenim gören öğretmen adaylarının Fransızcaya yönelik algılarının belirlenmesi, yakın gelecekte orta ve yükseköğretimde Fransızcayı yabancı dil olarak tercih edecek öğrencilerde bu dile değin olumlu bir tutum geliştirebilir. Algıların belirlenme yollarından biri de kişilerin bir kavram veya olguyu nasıl algıladığını benzetmeler kullanarak dile getirmesi, bir başka ifade ile metaforlar aracılığıyla anlatmasıdır (Aydın, 2010, s. 1296). Metafor kelime anlamı itibarıla Yunanca "metapherein" kelimesinden türemiş olup "meta" değiştirmek, "pherein" ise taşımak manasına gelmektedir (Levine, 2005, s. 172). Oxford Sözlük (Hornby 2000)'te ise "metafor: "İki şey arasında ortak özelliği göstermek ve güçlü bir betimleme yapmak, bir şeyi hayali olarak tasvir etmek için kullanılan sözcük ya da kavram" şeklinde tanımlanmaktadır. Araştırmacılar (Saban, Koçbeker \& Saban, 2006, s. 463).metaforun, yüksek düzeyde soyut ve anlaşllamayan karmaşı olanların anlaşlır hale getirilmesinde kullanılan zihinsel araçlar olarak olduğunu belirtmektedir.

Çoğu zaman bir söylemi süsleyerek anlatan bir söz sanatı olarak bilinse de metaforlar anlaşılmayan bir kavramı bilinen şeylerden yararlanarak ve onlara benzeterek daha kolay anlamamızı sağlarlar. İnsanlar her dilde ve kültürde bir konuyu açılamaya çalışırken daha iyi anlaşılması açısından metaforları kullanır. Metaforlar bir şeyin anlamını güçlendirir, bu aynı zamanda bizlere bu kültürde yaşayan insanların kendilerini ve dünyayı algılama biçimlerini de gösterir. Örneğin, bir savaşta savaşçılar için "aslanlar gibi savaştılar" ifadesi kullanılarak metafor yapılıyorsa, bu onların bir aslan gibi cesaretli ve güçlü olduklarına işaret etmek ve bu metafordan yararlanarak konuyu diğerleri için daha çabuk ve anlaşılır kılmaktır.

Alanyazın incelendiğinde metaforların yabancı dil eğitimi alanında da olgu ve kavramlara yönelik algıların belirlenmesinde kullanıldığı görülmektedir. Örneğin Karabük Üniversitesi Edebiyat Fakültesi İngiliz Dili edebiyatı öğrencileriyle gerçekleştirilen araştırmada, öğrencilerin "İngilizce" kavramına yönelik metaforları incelenmiştir (Tosuncuoğlu, 2018, s. 691). Bu araştırmada öğrencilerin İngilizceyi "insan”, “kavram”, “nesne”, “coğrafi terim”, "bitki”, “fiil” ve “yaşayan bir canlı” olarak kategorize ettikleri belirlenmiştir. Arap Dili Eğitimi lisansüstü öğrencileri ile gerçekleştirilen bir çalışmada (Yeşilyurt, 2017, s. 97) da, öğrencilerin standart Arapça kavramıla ilişkili olarak 13 metafor ürettikleri (anne, köprü, araba, güneş,...) ve Arapça diyalektleriyle ilişki olarak 12 metafor ürettikleri (hızlı tren, evlat, akıllı telefon, yemek, mevsimler,...) belirlenmiştir. Bunların yanı sıra Gömleksiz (2013, s. 649)'in yürüttüğü araştırmada ise öğretmen adaylarının yabancı dil kavramına ilişkin metaforik algıları belirlenmesi amaçlanmıştır. Araştırmada yabancı dil kavramına ilişkin 54 metaforun geliştirildiği, sekiz ayrı kavramsal kategori (gelecek, gereklilik, güç, keyif, seyahat, ümitsizlik, zorluk ve sömürgecilik) elde edilmiştir. Diğer taraftan eğitim fakültelerinin Fransız Dili Eğitiminde öğrenim gören öğrencilerin Fransızca kavramına ilişkin algılarının metaforlar aracılığıyla belirlenmesine yönelik herhangi bir çalışma ise bulunmamaktadır. 


\section{Amaç}

Metaforlar, zihindeki soyut ve belirsiz duyguların ve düşüncelerin somutlaştırılması için kullanılırlar. $\mathrm{Bu}$ düşünceden hareketle, Gazi Üniversitesi Fransız Dili Eğitimi Anabilim Dalı öğrencilerinin Fransızcaya dair algı ve düşüncelerinin neler olduğunun, başka bir deyişle bu dile dair kafalarında nasıl bir resim oluşturduklarının renk metaforu aracılı̆̆ıyla belirlenmesi ve bu metaforların (renklerin) seçiliş nedenlerinin ortaya konulması amaçlanmaktadır.

\section{Yöntem}

Eğitim bilimleri alanındaki soruları cevaplamak için bir dizi araştırma yöntemi geliştirilmiştir. Mevcut araştırma, bu yöntemlerden olgubilim (fenomenoloji) yöntemine göre gerçekleştirilmiştir. En geniş anlamıla olgubilimin (fenomenoloji) amacı, bireylerin herhangi bir durumda yaşadığı deneyimlere dayanarak ortak anlamların belirlenmesidir (Speziale \& Carpenter, 2011, s. 62-63). Bu araştırmada Gazi Üniversitesi Fransız Dili Eğitimi Anabilim Dalı öğrencilerinin Fransızcaya dair algı ve düşünceleri ile bu düşüncelerinin nedenleri belirlendiği için olgubilim deseni tercih edilmiştir.

\subsection{Araştırma grubu}

Araştırmanın çalışma grubu 2016-2017 Bahar yarıyılında bu anabilim dalında lisans 1. ve 4. sınıf düzeyinde öğrenim gören 62 (48’i kız; 14’ü erkek) gönüllü katılımcı öğrenciden oluşmaktadır. Adayların cinsiyet yönünden dağılımındaki farklılığın kaynağında, Türkiye'de Fransız Dili Eğitimi programlarının çoğunlukla kız öğrenciler tarafından tercih edilmesi yer almaktadır. Ayrıca birinci ve dördüncü sınıfların tercih edilmesinin nedeni ise, araştırmacılardan birisinin bu sınıf düzeylerinde ders vermesidir.

\subsection{Veri toplama aracı ve verilerin analizi}

Öğrencilerin yabancı dil olarak Fransızca kavramına ilişkin metaforik algıları yapılandırılmış yarı-açık uçlu Size göre Fransızca bir renk olsayd,, bu renk ne olurdu ve niçin bu renk olurdu? sorusuyla elde edilmiştir. Metaforun (rengin) ne olabileceği ne renk soru sözcük öbeğiyle belirlenmeye çalışılırken niçin soru ifadesi ile de metafor olarak tanımlanan rengin neden seçildiğinin arka planına ilişkin algıya/ değerlendirmeye ulaşılmaya çalışılmıştır. Verilerin analizinde ise içerik analizi tekniği kullanılmıştır. Öğrencilere ait cevaplar "Ö" (Öğrenci), "K"/"E" (Kız/Erkek) ve "1"/" " (1. Sinıf /4. Sinıf) kısaltmalarıyla Ö1-K1 ile Ö62-E4 arasında numaralandırılmıştır.

\section{Bulgular}

Araştırmanın bu bölümünde, veri analizlerinden elde edilen bulgular yer almaktadır. 


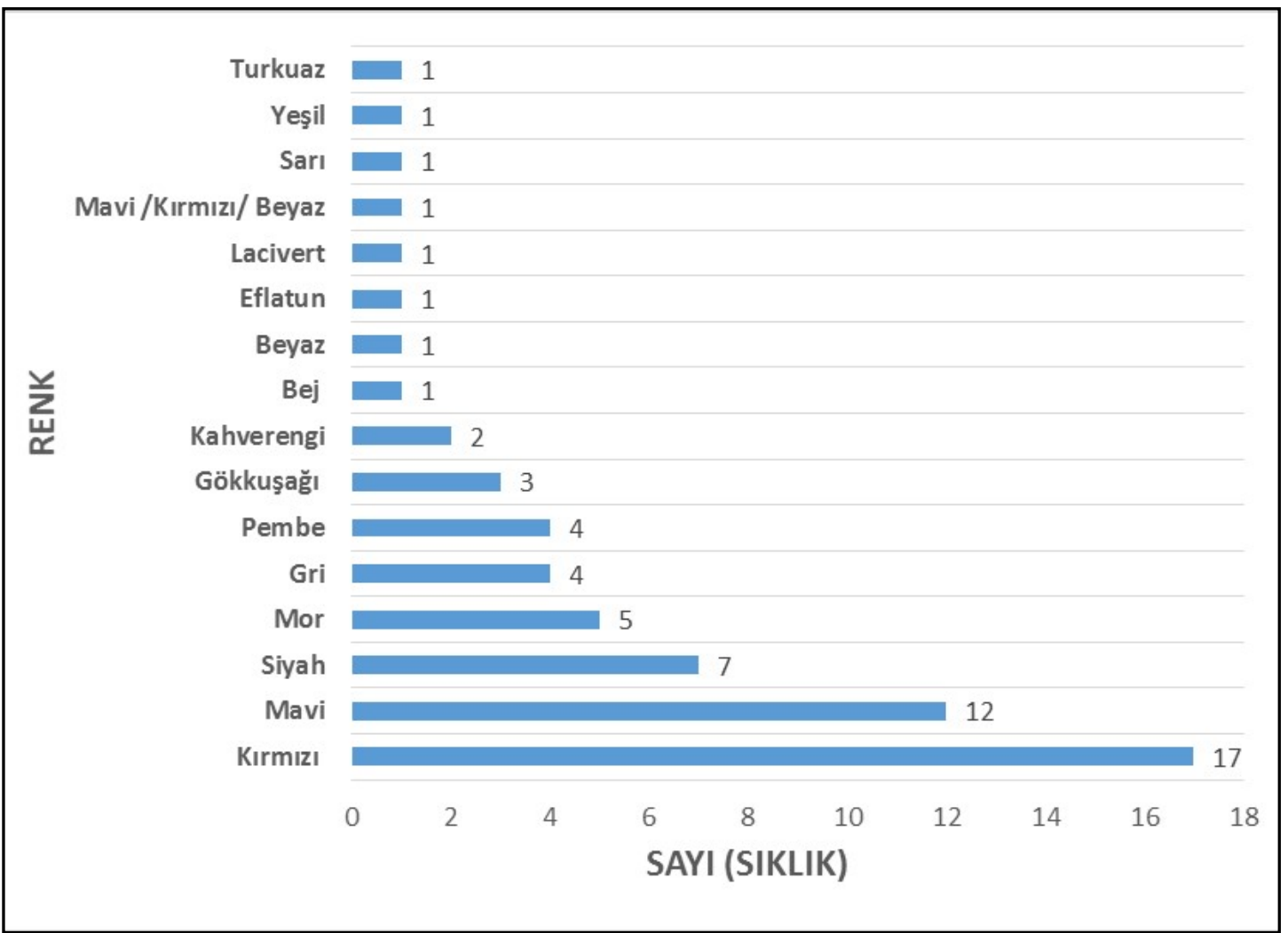

Grafik 1. Rek metaforlarının dağılımı

Araştırmaya katılan öğretmen adaylarının renk metaforu aracılığıyla Fransızcaya dair algı ve düşüncelerine yönelik analiz sonuçlarının yer aldı̆̆ı Grafik 1 iincelendiğinde, Fransızca ile ilk sırada en sıklıkla "kırmızı" rengin ilişkilendirildiği bunu ikinci sırada "mavi" rengin üçüncü sırada ise "siyah" rengin izlediği görülmektedir. Ayrıca grafiğin tamamına bakıldığında, Fransızcanın bir dil olarak katılımcılar tarafından kırmızıda maviye, mordan gökkuşağına ve turkuazdan beje kadar çok geniş bir yelpazede renk metaforu ile ilişkilendirildiği dikkat çekmektedir. 


\begin{tabular}{|c|c|c|}
\hline $\begin{array}{l}\text { Alt } \\
\text { Temalar } \\
\text { (f) }\end{array}$ & $\begin{array}{l}\text { Katılımci } \\
\text { Kodu }\end{array}$ & Alıntı \\
\hline \multirow{10}{*}{$\begin{array}{l}\text { Aşk } \\
(\mathbf{f}=\mathbf{1 0})\end{array}$} & Ö3-K1 & Bana tutkuyu, sevgiyi ve aşka çağrıştırıyor. \\
\hline & $\ddot{O}_{4}-\mathrm{K} 1$ & Aşkz, tutkuyu ve hırsı anımsatıyor. \\
\hline & $\mathrm{Ö}_{5}-\mathrm{K} 1$ & 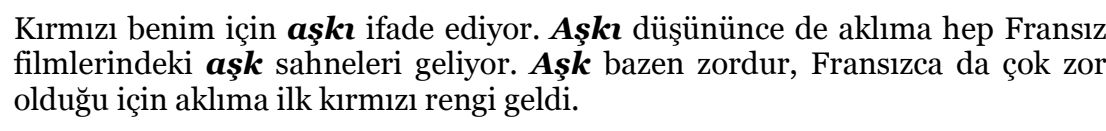 \\
\hline & Ö6-K1 & 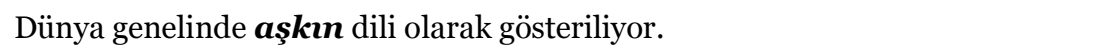 \\
\hline & $\ddot{O}_{7-\mathrm{K} 1}$ & Aşken rengi kırmızı, Fransızca da romantik. \\
\hline & Ö8-E1 & Aşken dili Fransızcadır. \\
\hline & Ö28-K1 & $\begin{array}{l}\text { Öğrenirken heyecan veren, konuşurken zorlayan, dinlerken } \hat{a} s ̧ \mathbf{k} \text { eden, } \\
\text { düşünürken hayallere daldıran bir dil, çok seviyorum. }\end{array}$ \\
\hline & Ö31-K1 & Romantizmin, duyguların ve aşken dili olduğu için. \\
\hline & Ö34-K4 & Bana aşka ve sevgiyi çağrıştırıyor. \\
\hline & Ö54-K4 & Bu dili bir $\boldsymbol{a s ̧ k m n ~ v e ~ r o m a n t i z m i n ~ b i r ~ s i m g e s i ~ o l a r a k ~ g o ̈ r u ̈ y o r u m ~ u z u n ~ y ı l l a r d ı r . ~}$ \\
\hline \multirow{5}{*}{$\begin{array}{l}\text { Tutku } \\
(\mathbf{f}=5)\end{array}$} & Ö3-K1 & Bana tutkuyu, sevgiyi ve aşkı çağrıştırıyor. \\
\hline & Ö4-K1 & Aşkı, tutkuyu ve hırsı anımsatıyor. \\
\hline & Ö34-K4 & Tutkunun dili, Fransızca bence kırmızı olmalı. \\
\hline & Ö48-K4 & Asil, tutkulu, zor ve güçlü bir dildir. \\
\hline & Ö6o-K4 & Fransızca aşk ve tutku dilidir. \\
\hline \multirow{4}{*}{$\begin{array}{l}\text { Konuşma } \\
(\mathbf{f}=4)\end{array}$} & Ö28-K1 & $\begin{array}{l}\text { Öğrenirken heyecan veren, konuşurken zorlayan, dinlerken âşık eden, } \\
\text { düşünürken hayallere daldıran bir dil, çok seviyorum. }\end{array}$ \\
\hline & Ö29-K1 & Konuşulduğunda dikkat çeken bir dil. \\
\hline & Ö34-K4 & $\begin{array}{l}\text { Konuştukça daha fazla bağlanıyorum. Tutkunun dili, Fransızca bence kırmızı } \\
\text { olmalı. }\end{array}$ \\
\hline & Ö6o-K4 & Tonlamasındaki naiflik insanın içinde aşkı ve huzuru hissettiriyor. \\
\hline \multirow{4}{*}{$\begin{array}{l}\text { Dikkat } \\
\text { çekme/ } \\
\text { Çekici/lik } \\
(\mathbf{f}=4)\end{array}$} & Ö29-K1 & Konuşulduğunda dikkat çeken bir dil. \\
\hline & Ö30-K1 & $\begin{array}{l}\text { Fransız dili zorlu ve güçlüklerle dolu bir dil ama kendine has ta bir çekiciliğgi } \\
\text { vardır. }\end{array}$ \\
\hline & Ö37-K4 & Çok akıcı ve insanı içine çeken bir dil olduğunu düşünüyorum. \\
\hline & $\ddot{O}_{48}-\mathrm{K}_{4}$ & ... Bu da onu ilgili, çekici ve tutkulu kılar. \\
\hline \multirow{3}{*}{$\begin{array}{l}\text { Zor } / \text { luk } \\
(\mathbf{f}=\mathbf{2})\end{array}$} & Ö5-K1 & Aşk bazen zordur, Fransızca da çok zor olduğu için aklıma ilk kırmızı rengi geldi. \\
\hline & Ö27-E1 & Zorluğuyla gözümüzü korkutuyor. \\
\hline & Ö28-K1 & $\begin{array}{l}\text { Öğgrenirken heyecan veren, konuşurken zorlayan, dinlerken âşık eden, } \\
\text { düşünürken hayallere daldıran bir dil, çok seviyorum. }\end{array}$ \\
\hline
\end{tabular}

Tablo 1. Öğretmen adaylarının "kırmızı" metaforundan elde edilen sonuçlar

Tablo 1'deki bulgular, araştırmaya katılan adayların Fransızcaya "kırmızı" renk metaforu aracılığıyla başta aşk alt teması olmak üzere sırasıyla tutku, konuşma, dikkat çekme/çekicilik ve zorluk olmak üzere altı alt temayla ilişkilendirdiğini göstermektedir. Katılımcıların bir kısmı için Fransızca aşk ve tutkuyu çağrıştırmaktadır. Bunun yanı sıra katılımcılar için Fransızca denildiğinde aynı zamanda aşkla birlikte aşk sahnesinin yer aldığı filmlerin ilişkilendirildiği (Ö5-K1) görülmektedir. Ayrıca katılımcıların kırmızı metaforunu tercih etme nedenleri arasında Fransızcanın konuşma boyutuna da dikkat çektikleri ve bu 
dilin konuşulmasına dair hayranlık düzeyindeki duygularını ifade ettikleri ve bu yönüyle dikkat çeken veya çekici bir dil olduğunu düşündükleri görülmektedir. Bununla birlikte "zorluk" alt temasında ise adaylar, özellikle de Fransızca konuşmada yaşanan zorlukları vurgulamaktadır.

\begin{tabular}{|c|c|c|}
\hline $\begin{array}{l}\text { Alt } \\
\text { Temalar (f) }\end{array}$ & $\begin{array}{l}\text { Katılımeı } \\
\text { Kodu }\end{array}$ & Alıntı \\
\hline \multirow{9}{*}{$\begin{array}{l}\text { Olumlu } \\
(\mathbf{f}=\mathbf{9})\end{array}$} & $\ddot{O}_{42-\mathrm{K}} 4$ & Özgür ruhlu bir dildir. \\
\hline & Ö47-K4 & Mavi özgürlü̆ğün simgesidir. Mavi temizliği ve ferahlığı temsil eder. \\
\hline & Ö57-E4 & $\begin{array}{l}\text { Bence mavi renk, özgürrlüğün ve barışın simgesidir. Fransız bayrağında } \\
\text { olduğu gibi. }\end{array}$ \\
\hline & Ö62-E4 & Özgürlüğü̈n simgesi. \\
\hline & Ö39-K4 & Ufkumu açan, yeni şeylere yelken açmamızı sağlayan bir dil. \\
\hline & Ö44-E4 & Deniz kadar geniş gökyüzü kadar uçsuz bucaksız geniş bir dildir. \\
\hline & Ö17-K1 & Mavi derinliktir, Fransızca da öyle. \\
\hline & Ö46-K4 & Mavi huzur veriyor bende. \\
\hline & Ö18-K1 & Fransizlar bu renge hasta. \\
\hline $\begin{array}{l}\text { Olumsuz } \\
(\mathbf{f}=\mathbf{1})\end{array}$ & Ö16-E1 & Soğuk bir ülke. \\
\hline $\begin{array}{l}\text { Nötr } \\
(\mathbf{f}=\mathbf{1})\end{array}$ & Ö19-E1 & Aklıma ilk mavi geldi. \\
\hline
\end{tabular}

Tablo 2. Öğretmen adaylarının "mavi” metaforundan elde edilen sonuçlar

Öğretmen adaylarının "mavi” metaforuna yönelik alt temalarının olumlu, olumsuz ve nötr olmak üzere üç başlık altında toplanmıştır. "Mavi” metaforu aracıllğıyla adaylardan bazıları Fransızcanın özgür ruhlu bir dil, özgürlük ve barışın simgesi olduklarını düşündüklerini belirtirken bazıları da Fransızcanın bir dil olarak zenginliğine dikkat çekerek ufuk açan, yeni şeylere yelken açılmasını sağlayan ve uçsuz bucaksız bir dil olduğunu ifade etmişlerdir. Diğer taraftan katılımcılardan birisi renk seçiminin nedenini Fransa'nın soğuk bir ülke olması şeklinde olumsuz bir anlam yükleyerek bir diğeri ise "aklına ilk gelen" renk olarak nötr bir düşünce sergileyerek ifade etmiştir. Bu sonuçlar, araştırmaya katılan ve metafor olarak "mavi" rengi belirten adayların büyük çoğunluğu için Fransızcanın olumlu düşünceler çağrıştırdığını göstermektedir.

\begin{tabular}{|c|c|c|}
\hline Alt tema & $\begin{array}{l}\text { Katılımeı } \\
\text { Kodu }\end{array}$ & Alıntı \\
\hline $\begin{array}{l}\text { Olumlu } \\
(\mathbf{f}=\mathbf{1})\end{array}$ & Ö10-K1 & En sevdiğim renk. \\
\hline \multirow{3}{*}{$\begin{array}{l}\text { Olumlu ve } \\
\text { olumsuz } \\
(\mathrm{f}=3)\end{array}$} & Ö15-K1 & $\begin{array}{l}\text { Ben ne zaman siyah bir renk görsem sonsuzluk, bitmemezlik aklıma geliyor. } \\
\text { Fransızca ise aynı şekilde; sonsuz kelime hazinesi ve zorluğuyla bana } \\
\text { siyahı çağrıştırıyor. }\end{array}$ \\
\hline & Ö33-K1 & Beni zorladı̆̆ını ama aynı zamanda çektiğini, zevk aldı̆̆ımı hissettiriyor. \\
\hline & Ö1-K1 & Bazen içimi kararthyor ama bazen hoşuma gidiyor. \\
\hline \multirow{3}{*}{$\begin{array}{l}\text { Olumsuz } \\
(\mathbf{f}=\mathbf{3})\end{array}$} & Ö45-K4 & İçim karardr. \\
\hline & Ö49-K4 & Bu dil benim için öğrenmesi zor bir oldu. \\
\hline & Ö53-K4 & $\begin{array}{l}\text { Gramatikal anlamda çok zor bir dil olduğunu düşünüyorum. Bu yüzden } \\
\text { öğrenirken çok karamsardım. Bende karanlk bir his uyandırıyor. }\end{array}$ \\
\hline
\end{tabular}

Tablo 3. Öğretmen adaylarının "siyah" metaforundan elde edilen sonuçlar 
The colour of French language: The metaphorical perceptions of prospective teachers on French as a foreign language / M. Alpar; E. Kartal (pp. 405-416)

Araştırmaya katılan adaylardan yedisi Fransızcayı metafor olarak "siyah" renk ile ilişkilendirmişlerdir. Bu renkle ilişkilendiren adaylardan sadece biri bu rengin en çok sevdiği renk olması nedeniyle bunu tercih ettiğini ifade etmiştir. Diğer taraftan adaylardan üçü siyah renk ile Fransızcanın kendileri için hem sonsuzluk, zevk alma ve hoşuna gitme gibi olumlu düşünceleri çağrıştırdığını hem de zorluk ve içini karartma gibi olumsuz durumları çağrıştırdığını belirtmiştir. Siyah renk ile adaylardan üçü de Fransızcanın kendileri için sadece içini karartma, konuşamama ve öğrenilmesi çok zor olma gibi olumsuz durumları düşündürdüğünü dile getirmiştir. Bu konudaki düşüncelerini adaylardan birinin (Ö49-K4)şu şekilde belirttiği görülmüştür: "Bu dil benim için öğrenmesi zor bir oldu. Hala konuşamıyorum. Fransızcayı sevemedim."

\begin{tabular}{|c|c|c|}
\hline \multirow{5}{*}{ Mor } & Ö13-K1 & $\begin{array}{l}\text { Bence Fransızca da mor gibi bunaltıcı. Yani her zaman değil ama ben her zaman } \\
\text { çalışmaya başladığımda öyle hissediyorum. }\end{array}$ \\
\hline & Ö14-K1 & Bazen zor gelse de dilin renginin güzelliği sevdirir. \\
\hline & Ö20-K1 & Zor olmasına rağmen her zaman ilgi çekici. \\
\hline & Ö21-K1 & Hem huzur verici bazen de daraltıcı. \\
\hline & Ö59-K4 & $\begin{array}{l}\text { Mor renk bana göre çok asıl bir renk ve çok severim. Fransizca da en } \text { asil bir dil } \\
\text { olduğuna göre mordan başka bir renk düşünmedim. }\end{array}$ \\
\hline \multirow{4}{*}{ Pembe } & Ö2-K1 & En sevdiğim renk ve en sevdiğim dille aynı olmalı. \\
\hline & Ö41-K4 & $\begin{array}{l}\text { Pembe bir şey giydiğimde ya da pembe bir şey gördüğ̈̈mde nasıl mutlu oluyorsam } \\
\text { Fransizca ile iç içeyken de o kadar mutlu oluyorum. }\end{array}$ \\
\hline & $\ddot{O}_{50}-\mathrm{K}_{4}$ & Pembe çok güzel. Her yer pembe olsa mesela deniz, insanlar daha mutlu olur. \\
\hline & $\ddot{O}_{58} 8-\mathrm{K} 4$ & İnce ve kırılgan bir dil gibi. \\
\hline \multirow{4}{*}{ Gri } & Ö22-E1 & Hayatı "gri" de yaşamak güzeldir. \\
\hline & Ö25-K1 & $\begin{array}{l}\text { Hem kasvetli hem de her şeye yakışan bir renk olurdu. Benim de en sevdiğim } \\
\text { renktir. Hem zor hem güzel. }\end{array}$ \\
\hline & Ö38-E4 & $\begin{array}{l}\text { Ben bu dilde yeterli olmadiğım hissediyorum. Eğer yeterli olduğumu } \\
\text { hissetseydim beyaz veya hiç bilmediğimi hissetseydim siyah derdim. Arada bir } \\
\text { yerde olduğum için gri demek istiyorum. }\end{array}$ \\
\hline & Ö61-K4 & $\begin{array}{l}\text { Ne beyaza yakın ne de siyaha. Bazen beyaz kadar huzur verici, akıcı. Bazen de siyah } \\
\text { kadar boğucu, sıkıntıl. }\end{array}$ \\
\hline \multirow{3}{*}{ Gökkuşağı } & Ö11-K1 & Her duyguyu ve her hissi aynı anda barındırıyor. \\
\hline & Ö12-K1 & Her renginde farklı bir eğlence farklı bir zorluk var. \\
\hline & Ö23-K1 & Konuşması dinlemesi çok güzel ama bir o kadar da zor ve bazen bunaltıcı. \\
\hline \multirow{2}{*}{ Kahverengi } & Ö35-E4 & $\begin{array}{l}\text { Rengin adı bile Fransızca gibi özgün. Kahverengi kapalı bir renk Fransızca da içine } \\
\text { dönük bir dil. }\end{array}$ \\
\hline & $\ddot{O}_{51-K 4}$ & Resmi ve $\boldsymbol{a} \breve{g} \mathbf{z r}$ bir dil \\
\hline
\end{tabular}

Tablo 4. Öğretmen adaylarının “mor, pembe, gri, gökkuşağı, kahverengi” metaforlarından elde Edilen sonuçlar

Metafor olarak "mor" rengi tercih eden adaylar, bu durumu olumlu ve olumsuz olmak üzere iki nedenle tercih ettiklerini belirtmişlerdir. Mor renk adaylar için Fransızcanın bunaltııı, daraltıcı ve zor olduğu kadar ilgi çekici dilin renginin güzel olması, huzur verici ve asil bir dil olmasıyla ilişkilendirilmiştir. Adaylar arasında metafor olarak "pembe" rengi tercih edenlerin Fransizcaya en sevdiği renk, mutlu olmak ve kırılgan bir dil olmak şeklinde olumlu anlamlar yükledikleri görülmektedir. "Gri” rengi metafor olarak tercih eden adaylar, Fransizcanın kendilerini zaman zaman farklı duygular hissettirmesi nedeniyle bu renkle Fransızcayı ilişkilendirdiklerini belirtmiştir. Adaylardan biri (Ö38-E4) bu durumu şu şekilde dile getirmiştir: "Ben bu dilde yeterli olmadı̆̆ımı hissediyorum. Ĕ̆ger yeterli olduğumu 
hissetseydim beyaz veya hiç bilmediğimi hissetseydim siyah derdim. Arada bir yerde olduğum için gri demek istiyorum." Ayrıca "gökkuşă̆ı"nı metafor olarak belirten adayların da "gri”" renge benzer şekilde olumlu ve olumsuz duyguları hissettiklerini ifade etmişlerdir. Bunların yanı sıra Fransızcayı metafor olarak "kahverengi" ile açılayanlardan biri (Ö35-E4), bunu dilin özgün olması ile açlklarken bir diğerinin (Ö51-K4) ise dilin resmi ve ağır olması ile açılladığı görülmektedir.

\begin{tabular}{|c|c|c|}
\hline Renk & $\begin{array}{l}\text { Katılımeı } \\
\text { Kodu }\end{array}$ & Alıntı \\
\hline $\begin{array}{l}\text { Mavi-Kırmizi- } \\
\text { Beyaz }\end{array}$ & Ö36-K4 & Bayraklarının renkleri. \\
\hline Lacivert & Ö32-K1 & İçinde mavinin güzelliği ve siyahın zorluğunu barındırıyor. \\
\hline Turkuaz & Ö24-K1 & $\begin{array}{l}\text { Turkuaz rengi bana her zaman huzur verir ve Fransızca konuşan birini } \\
\text { dinlemek gibi. }\end{array}$ \\
\hline Yeşil & Ö $55-K_{4}$ & Fransızca konuşurken doğanın verdiği huzuru hissettirdiği için yeşil. \\
\hline Bej & Ö56-E4 & $\begin{array}{l}\text { Çok arada bir dil. Latince ve Germen dillerinin biraz etkisinde kalmış ama tek } \\
\text { başına dünyaya damga vurmayı başarmış. Bej de öyle, beyaz, gri, sarı, pembe } \\
\text { gibi bir sürü ara renkten beji elde edebilirsiniz. Bej de güzel bir renk olduğuna } \\
\text { göre Fransızca da öyle. }\end{array}$ \\
\hline Beyaz & Ö $40-\mathrm{K}_{4}$ & Beyaz bende temizlik, saflık ve berraklığı temsil ediyor. \\
\hline Eflatun & $\ddot{O}_{52}-\mathrm{E} 4$ & Diğer bütün dillerden daha farklı ve daha romantik ve daha flu \\
\hline
\end{tabular}

Tablo 5. Öğretmen adaylarının "mavi-kırmızı-beyaz, lacivert, turkuaz, yeşil, bej, beyaz, eflatun" metaforlarından elde edilen sonuçlar

Yedi farklı rengin metafor olarak yer aldığı tablodaki bulgular incelendiğinde, araştırmaya katılan adayların bu renklerin tamamını öncelikle bayrak rengi, güzellik, huzur verici, temizlik, romantik olma gibi olumlu durumlarla ilişkilendirdiği görülürken sadece "lacivert" rengi metafor olarak gösteren adayın (Ö32-K1) bu renk içindeki siyahı Fransızcanın zorluğu olarak nitelendirdiği görülmektedir.

\section{Tartışma ve sonuç}

Fransız Dili Eğitimi öğretmen adaylarının renk metaforu aracıllğıyla Fransızcaya dair algı ve düşüncelerinin belirlenmesinin amaçlandığı araştırmada, bir dil olarak Fransızcanın ana, tamamlayıcı ve ara renk (Türkoğlu, 2003, s. 279) olmak üzere birçok renkle ilişkilendirildiği belirlenmiştir. Bu renkler arasında ilk sırayı kırmızı almaktadır. Kırmızı, ana renklerden biridir. Kırmızı, yaşamın temel belirtisi, canlılık, güzellik, soylu ve erişilmez güç, gençlik, sağlıklı olma, zenginlik ve özgürlüğün simgesi olarak görüldüğü gibi aynı zamanda aşk, tutku ve neşe, samimiyet, hoşlanma gibi duyguların rengi olarak da görülmektedir (Türkoğlu, 2003, s. 284). Nitekim Fransızcayı metafor olarak kırmızı ile ilişkilendiren öğretmen adayları da bu renkle ilişkilendirme nedenlerini Fransızcanın aşk ve tutku dili olmasıyla açıklamışlardır. Bunların yanı sıra kırmızı rengin olumlu duyguları yansıtıyor olmasına dayanarak öğretmen adaylarının Fransızcaya olan sevgisini de gösterdiği söylenebilir. Ayrıca adayların bir bölümü Fransızca öğrenmenin güçlüklerine karşın bu renkle Fransızcayı asil, insanların ilgisini çeken ve merak uyandıran bir dil olarak algılamaktadır. Bu da tüm zorluklara karşın öğrencilerin bu dili öğrenmeye dair istekli olduklarını göstermektedir.

Kırmızı renginden sonra öğretmen adaylarının Fransızcayı en sıklıkla ilişkilendirdikleri rengin ana renklerden biri olan mavi olduğu belirlenmiştir. İnsanlara huzur, rahatllk ve mutluluk veren, doğru düşünme-olumlu karar verme ve yaratıcılığın gelişmesi gibi özellikleri içinde bulunduran (Topal, 2017), 
gökyüzü ve suyun rengi olarak bilinen mavi, genel olarak sonsuzluk ve huzurun rengi olarak görülmektedir (Çalışkan \& Kılıç, 2014, s. 75).

Araştırmaya katılan öğrenciler de mavi metaforu ile Fransızcanın onlar için özgürlük, barış ve sonsuzluğu temsil ettiğini aynı zamanda Fransız kültür, edebiyat ve tarihiyle onlara yeni ufuklar açan uçsuz bucaksız bir dil olduğunu belirtmişlerdir. Bu bağlamda özellikle de özgürlük ve barış ile mavi rengi ilişkilendirmelerinin kaynağında özellikle de 1789 Fransız Devrimi'yle özürlüğü bütünleştirdikleri görülmektedir. Benzer şekilde Amasya Üniversitesi Eğitim Fakültesi dördüncü sınıf öğretmen adaylarının renk dünyalarını tanıma ve renklere ilişkin algılarının belirlenmesi amacıyla gerçekleştirilen araştırmada (Zeren \& Yapıcı, 2014, s. 172), adayların mavi renk ile en sıklıkla deniz ( $\mathrm{f}=10)$, huzur $(\mathrm{f}=8)$, gökyüzü ( $f=5)$, mutluluk ve özgürlüğü $(\mathrm{f}=4)$ ilişkilendirdikleri belirlenmiştir.

Siyah araştırmada öğretmen adayları tarafından Fransızca ile ilişkilendirilen ve en çok tercih edilen üçüncü renk olmuştur. Güç, soyluluk, ağırbaşlılık, otorite, akıl, erdem, gizem, mutsuzluk, hayal kırıklığı, verim, bereket, temizlik gibi birbirine zıt olan farklı anlamlar yüklenmiş (Çalışkan \& Kılıç, 2014, s. 73) bir renk olarak görülen siyah aynı zamanda karamsarlık ve kötülüğün rengi olarak da görülmektedir (Türkoğlu, 2003, s. 281). Araştırmaya katılan öğretmen adaylarının Fransızca ile siyah renge dair ilişkilendirmeleri de bu yaklaşımları doğrular niteliktedir. Bunların arasında katılımcılardan birinin hala Fransızcayı konuşamadığına dair açıklamaları siyah için yüklenen karamsarlık yönünü de doğrulamaktadır. Ayrıca öğretmen adaylarının kırmızı ve mavi rengi çoğunlukla olumlu olarak anlamlandırırken, siyah rengi ise olumsuz olarak değerlendirdiği görülmektedir. Nitekim Fransızcayı öğrenmenin zorlukları, öğrencilerin siyah rengi seçme nedenlerine yönelik düşünceleriyle de doğrulanmıştır. Bu noktada Fransızcanın dili aşkı, tutkuyu ve romantizmi çağrıştırması nedeniyle sevilen bir dil olmasına rağmen gramer yapısı ve yazılışı itibarıyla öğrenilmesinin zor olmasının öğrencilerin üzerinde bir baskı yarattığı görülmektedir. Bu nedenle bu dili öğrenmeye teşvik edici unsurların etkin kılınması yoluyla dili öğrenmeye dair zorluk algısının daha başlangıçtan itibaren önlenmesiyle dile dair yaklaşımların olumlu yönde değişmesi sağlanabilir.

Öğretmen adayları tarafından Fransızca ile ilişkilendirilen renkler arasında iki rengin karışımından oluşan ve ara renk olarak adlandırılan pembe, gri ve mor renkler de yer almaktadır. Bunlar arasında araştırmaya katılan öğretmen adaylarının bir kısmı tarafından yatıştırııı ve sakinleştirici bir renk olarak görülen mor renk (Türkoğlu, 2003, s. 288), bir kısmı tarafından ise daraltıcı, bunaltıcı ve zor olarak görülmüştür. Önceki araştırma sonuçları incelendiğinde öğretmen adaylarının mor renk ile en sıklıkla asalet $(\mathrm{f}=4)$, depresyon, gece, menekşe ve hüzün $(\mathrm{f}=2)$ kavramlarını ilişkilendirdikleri görülmüştür. Ayrıca Başbınar Aktekin, Şimşek ve Kaplan (2011, s. 32), mor rengin kasvet, depresyon ve hüznü simgelediğini belirtmektedir. Bu yaklaşımlar aynı zamanda, katılımcıların Fransızcayı hem öğrenilmesi zor bir dili oluşuna dair hem de aynı zamanda ilgi çekici bir dil oluşuna dair düşüncelerini doğrulamaktadır.

Çoğunlukla kırmızının olumlu anlamlarını taşıdığı ve iyimser duygular uyandırdığı (Türkoğlu, 2003, s. 287) düşünülen pembe renk, öğretmen adayları tarafından en sevilen renk, mutlu olmak ve kırılgan bir dil olmakla ilişkilendirilmiştir. Nitekim Başbınar Aktekin, Şimşek ve Kaplan (2011, s. 32)'ın yüksekokul öğrencileriyle gerçekleştirdiği araştırmada pembe rengin en fazla masumiyet ve neşe ile ilişkilendirildiği belirlenmiştir.

Topal (2017) tarafından üzüntülü ve sıkıntılı duyguları ifade ettiği belirtilen gri renk, Çalışkan ve Kılıç (2014, s. 76) tarafından ise ağırbaşlıllık ve sadakatin rengi olarak görülmektedir. Bir yönüyle üzüntülü ve 
sıkıntılı duygulara yapılan vurgu ile mor renge yüklenen kasvet ve hüznü çağrıştırırken diğer yönüyle ise sadakat ile güçlü duyguları çağrıştıran kırmızı renge yüklenen anlamlar bir araya gelmiştir gride. Araştırmaya katılan öğretmen adayları da tüm bu karmaşı duyguları hissederek Fransızca ile gri rengi ilişkilendirmişlerdir. Ayrıca gökkuşağı metaforu ile Fransızcanın ilişkilendirilmesi, hem dil öğrenme sürecinde yaşanan karmaşık duyguları düşündürmekte hem de dil, edebiyat, sanat ve tarihiyle yani Fransızcanın ve Fransa'nın tüm renklerini içine alan bütüncül bir yaklaşımla dilin ele alındığını da göstermektedir.

Sonuç olarak Fransızcanın hangi rengi çağrıştırdığı ile ilgili araştırma sonuçları, öğretmen adaylarının ana (kırmızı, mavi, sarı), tamamlayıcı ( turuncu, yeşil) ve ara renkler (pembe, gri ve mor) olmak üzere Fransızcayı yeryüzündeki tüm renklerle ve beraberinde birçok duyguyla ilişkilendirdiğini göstermektedir. Bunların arasında Fransızcanın aşk, tutku ve özgürlüğün rengi olarak görüldüğü bununla birlikte özellikle de başlangıçta Fransızcayı öğrenmeye dair yaşanan kimi güçlükler nedeniyle öğretmen adaylarının zaman zaman zorlanıp bunaldıkları, bu nedenlerle de ikilemler yaşadıkları görülmektedir. Bu bağlamda katılımcılardan birinin düşüncelerinin bu durumu en güzel şekilde özetlediği düşünülmektedir: "Öğrenirken heyecan veren, konuşurken zorlayan, dinlerken aşlk eden, düşünürken hayallere daldıran bir dil”.

\section{Kaynakça}

Aksoy, E. (2015). Başlangıcından günümüze Türkiye'de Fransız okulları. Synergies Turquie, 8, 29-46.

Alpar G.(2015). Strateji ve savaş kültürünün gelişimi. Konya: Palet.

Alpar, G. (2019). Geçmişten günümüze kültürel unsurların sömürge amaçlı kullanımı. Al-Farabi Uluslararast Sosyal Bilimler Dergisi, 3(1), 204-218.

Aydın, F. (2010). Ortaöğretim öğrencilerinin coğrafya kavramına ilişkin sahip oldukları metaforlar. Kuram ve Uygulamada Eğitim Bilimleri, 10(3), 1293-1322.

Başpınar Aktekin, D., Şimşek, Y., \& Kaplan, B. ( 2011). Renklerin duygular üzerine etkisi. Maltepe Tip Dergisi, 3(1), 31-33.

Çalışkan, N.,\& Kılıç E. (2014). Farklı dillerde ve eğitim süreçlerinde renklerin dili. Ahi Evran Üniversitesi Eğitim Fakültesi Dergisi, 15(3), 69-85.

Demirel, Ö. (1999). İlköğretim okullarında yabancı dil öğretimi. İstanbul: Milli Eğitim Basımevi.

Gömleksiz, M. N (2013). Öğretmen adaylarının yabancı dil kavramına ilişkin metaforik algıları. Turkish Studies-International Periodical for the Languages, Literature and History of Turkish or Turkic, 8(8), 649-664.

Hornby A.S. (2000). Oxford Advanced Learner's Dictionary of Current English (6 th $^{\text {th }}$ Edition). Oxford, United Kingdom: Oxford University Press.

Levine, P.M. (2005). Metaphors and images of classrooms. Kappa Delta Pi Record Summer, 41(4), 172175. doi.org/10.1080/00228958.2005.10532066

Saban, A. Koçbeker, B. N., \& Saban A. (2006). Öğretmen adaylarının öğretmen kavramına ilişkin algılarının metafor analizi yoluyla incelenmesi. Kuram ve Uygulamada Eğitim Bilimleri, 6(2), 461-522.

Sakaoğlu, N. (1991). Osmanh eğitim tarihi. İstanbul: İletişim.

Speziale, H.J., \& Carpenter, D.R. (2011). Qualitative research in nursing: Advancing the humanistic imperative ( $5^{\text {th }}$ Edition). Philadelphia, USA: Lippincott Williams \& Wilkins. Available from: https://oysconmelibraryo1.files.wordpress.com/2016/o9/qualitative-research-in-nursingadvancing-the-humanistic-imp.pdf , Erişim tarihi: 10.09.2019. 
The colour of French language: The metaphorical perceptions of prospective teachers on French as a foreign language / M. Alpar; E. Kartal (pp. 405-416)

Topal, D. (15 Mart 2017). Renkler psikolojimizi nasıl etkiler? Dergi PDR. Çevrimiçi: http://www.dergipdr.com/renkler-psikolojimizi-nasil-etkiler-4418h.htm, Erişim tarihi: 12.10.2019.

Tosuncuoğlu, Y . (2018). İngiliz dili ve edebiyatı bölümü öğrencilerinin "İngilizce" kavramına ilişkin metaforları. Türkiye Sosyal Araştırmalar Dergisi, 22(2), 677-697.

Türkoğlu, S. (2003). Anlatım ve deyimlerde renklerin dili. Atatürk Üniversitesi Kazım Karabekir Eğitim Fakültesi Dergisi, 8, 277-290.

Yeşilyurt, A . (2017). Arap dili eğitimi lisansüstü öğrencilerinin standart Arapça ve Arapça diyalektlere ilişkin algılarının belirlenmesi: Bir metafor analizi çalışması. Sınırsız Eğitim ve Araştırma Dergisi, 2(2), 86-102.

Yllancıoğlu, S. S (2011). Le Français, langue de la modernisation en Turquie. İçinde Marina Geat (dir.). La Francophonie et l'Europe (pp. 47-58). Rome: Artemide.

Zeren, G., \& Yapıcı, M. (2014). Öğretmen adaylarının renklere ilişkin metaforları. International Journal of Social Science, 25, 165-175. 